\title{
Dustborne microorganisms in the atmosphere over an Asian dust source region, Dunhuang
}

\author{
Makiko Kakikawa • Fumihisa Kobayashi • \\ Teruya Maki • Maromu Yamada • Tomomi Higashi • \\ Bin Chen • Guangyu Shi • Chunsang Hong • \\ Yutaka Tobo • Yasunobu Iwasaka
}

Received: 7 September 2008 / Accepted: 12 December 2008 / Published online: 16 January 2009

(C) The Author(s) 2009. This article is published with open access at Springerlink.com

\begin{abstract}
The dust event injects microorganisms into the atmosphere and could facilitate the dispersal of biological particles affecting leeward ecosystem and human health. In this study, the dustborne microorganisms in the atmosphere over the Taklimakan Desert, Asian dust source, were identified by culture-independent method. Dusts were collected using a balloon at about $800 \mathrm{~m}$ above the ground in an Asian dust source region, Dunhuang. After DNA were directly extracted from the dusts collected filters, $16 \mathrm{~S}$ and $18 \mathrm{~S}$ rRNA genes of microorganisms were amplified, cloned, and
\end{abstract}

Presented at the 5th Int Workshop on Sandstorms and Associated Dustfall, Urumqi, China, 22 May 2008

M. Kakikawa ( $\square)$

Institute of Nature and Environmental Technology,

Kanazawa University,

Kanazawa, Japan

e-mail: kakikawa@magstar.ec.t.kanazawa-u.ac.jp

F. Kobayashi $\cdot$ T. Maki

Graduate School of Natural Sience and Technology,

Kanazawa University,

Kanazawa, Japan

M. Yamada

Faculty of Environmental and Symbiotic Sciences,

Prefectural University of Kumamoto,

Kumamoto, Japan

T. Higashi

Graduate School of Medical Science, Kanazawa University,

Kanazawa, Japan

B. Chen · G. Shi

Institute of Atmospheric Physics, Chinese Academy of Sciences,

Beijing 100029, China

C. Hong $\cdot$ Y. Tobo $\cdot$ Y. Iwasaka

Frontier Science Organization, Kanazawa University,

Kanazawa, Japan sequenced. The rDNA sequence data indicated that dust particles include fungi closely related to Rickenella fibula, Ceriporiopsis gilvescens, and bacteria belonging to the genus Brevibacillus, Staphylococcus, Rhodococcus, Delftia, Pseudomonas, and Agrobacterium tumefaciens. These results suggest that dust particles in the atmosphere over Dunhuang could carry these many fungi and bacteria and might play a significant role in leeward ecosystem.

Keywords Asian dust · Dustborne · Microorganism · Bacteria $\cdot$ Fungi

\section{Introduction}

Asian dust from China is blown eastward across Korea, Japan, and the Pacific Ocean (Duce et al. 1980; Tsunogai and Kondo 1982). The global scale transport of Asian dust has been demonstrated by the chemical and radiological analysis of deposited dust in Hawaiian soil (Kennedy et al. 1998; Chadwick et al. 1999), the Greenland ice core (Biscaye et al. 1997), and St. Elias mountain, Canada (Zdanowicz et al. 2006). The major sources of Asian dusts are the Taklimakan Desert, Loess Plateau, and Gobi Deserts. However, dust events from the sources have different characteristics and contributions to downwind regions. Sun et al. (2001) suggested that dusts from the Gobi Deserts of Mongolia and Northern China can only be entrained to an elevation of $<3,000 \mathrm{~m}$ and deposited mainly in the proximal region in most cases. On the other hand, dust particles from Taklimakan Desert can be entrained to an elevation of $>5,000 \mathrm{~m}$ and then transported over long range by the westerlies since area to the north, west, and south of the Taklimakan Desert are surrounded by high mountains (average elevation $>5,000 \mathrm{~m}$ ) and open area of the desert 
exists only in the east margin. Dust particles, which cannot move up over the surrounding mountains, were well mixed about from several hundred meters to $6 \mathrm{~km}$ above the ground at Taklimakan Desert, Tarimu basin (Iwasaka et al. 2003; Yamada et al. 2005). Kurosaki and Mikami (2005) indicated that there are frequent floating dusts in the Taklimakan Desert even in summer because of the steep topographical surroundings. The floating dusts are rarely observed in the Gobi Desert and Loess Plateau. By lider measurements, the weak dusts were detected in the free troposphere over Japan during periods with no evident dust outbreak or even in seasons other than spring (Iwasaka et al. 1988; Sakai et al. 2000). Some investigators suggested that weak Asian dust events make possible contribution of biogeochemical cycle of the land, atmosphere, and ocean (Iwasaka et al. 2003; Matsuki et al. 2003; Yamada et al. 2005).

In recent years, many epidemiological studies have shown that Asian dust events are associated with an increase in risk of mortality and patients of cardiovascular and respiratory illness in Korea (Kwon et al. 2002; Park et al. 2005; Lee et al. 2007) and Taiwan (Chen et al. 2004; Chen and Yang 2005; Chan et al. 2008).

There is also a report that lipopolysaccharide and $\beta$-glucan have been detected in Asian dust particles (Ichinose et al. 2005). Lipopolysaccharide is the major component of outer membrane of Gram-negative bacteria (Nikaido and Vaara 1985) and induces or aggravates a variety of respiratory disease (Tulic et al. 2000; Wu et al. 2002). $\beta$-glucan is a component of cell wall of fungi (Shaun and Stephen 2006) and relates to respiratory tract inflammation (Vassallo et al. 2000; Hahn et al. 2003).

In fact, four research groups have detected bacteria and fungi in Asian dust by culture-based or microscopic analyses, in the last decade (Choi et al. 1997; Yeo and Kim 2002; Wu et al. 2004; Ho et al. 2005). Dustborne microorganisms aerosolized by African desert winds have been also investigated by culture-based methods (Griffin et al. 2001, 2003, 2006, and 2007; Kellogg et al. 2004; Prospero et al. 2005).

These desert dust events can facilitate long-distance dispersal of these dustborne microorganisms. The microorganisms should be considered as an important factor which affects air quality, human health, and downwind ecosystem.

In conventional culture-based method, however, only $1 \%$ of environmental microorganisms is culturable on any given medium (Torsvik et al. 1990). That is, about $99 \%$ of the total microorganisms in environment are unable to be detected or analyzed under laboratory conditions. It is essential to clarify the all dustborne microorganisms and the role and dynamics of microbial communities in air quality.

On the other hand, DNA isolated directly from dusts could provide genetic information of the unculturable microorganisms. Remarkable advances have been made recently in microbiology of soil and aquatic environments using culture-independent, molecular approaches (Rondon et al. 2000; Moon-van der Staay et al. 2001; Lopez-Garcia et al. 2001; Dawson and Pace 2002; Venter et al. 2003).

In this study, we investigated the dustborne microorganisms in the atmosphere over the Dunhuang, which is located in east open area of the Tarimu basin (Taklimakan Desert), by culture-independent metagenomic rDNA analysis.

\section{Materials and method}

Dusts samplings were performed in Dunhuang $\left(40^{\circ} 10^{\prime} 00^{\prime \prime}\right.$ N, 94 $40^{\prime} 60^{\prime \prime}$ E), Gansu Province, China, on August 17, 2007. Dunhuang City is located in the eastern part of Taklimakan Desert. Dust event was not observed on our sampling day by Meteorologial Bureau of Dunhuang city. The wind was calm at the ground on our sampling day. Airborne dusts were collected on $0.45 \mu \mathrm{m}$ pore-size filters by a vacuum pump using a balloon, at 800 and $10 \mathrm{~m}$ above the ground. Before the sampling, $0.45-\mu \mathrm{m}$ filters were autoclaved and set to bio-aerosol sampler aseptically. Samplings were performed by remote control when the balloon had reached the target altitude (Yamada et al. 2005). It was estimated that the Asian dusts in about $0.7 \mathrm{~m}^{3}$ of atmospheric air was collected on filter, by using the vacuum pump for $1 \mathrm{~h}$. The particle counter (KR-12A, RION CO., Ltd.) and thermohygrometer (EX-501, EMPEX Instruments, Inc.) were used with the balloon during the dust sampling.

DNA was extracted from dusts on the collected filter using cell wall lytic enzyme, lysozyme and proteinase K (SigmaAldrich). 16S rDNA for prokaryote was amplified by polymerase chain reaction (PCR) as described by Weisburg et al. (1991) $18 \mathrm{~S}$ rDNA for eukaryote was amplified by PCR using primer F1 (5'-TGGTTGATCCTGCCAGAGG-3') and R1 (5'-GGCTACCTTGTTACGACTT-3'). Each PCR reaction mixture (vol. $20 \mu \mathrm{l}$ ) included the following: $4 \mu \mathrm{l}$ of $5 \times$ Buffer, $1.6 \mu \mathrm{l}$ of $10 \times$ dNTP $(2.5 \mathrm{mM}$ each, dATP, dCTP, dGTP, dTTP), $0.2 \mu \mathrm{l}$ of each primers $(20 \mathrm{mM}), 12.8 \mu \mathrm{l}$ of sterile deionized $\mathrm{H}_{2} \mathrm{O}, 1 \mathrm{U}$ of PrimeSTAR DNA polymerase (TAKARA BIO INC.), $1 \mu \mathrm{l}$ of DNA ( 30 ng). Thermal cycler (Dice, TAKARA BIO INC.) was used under the following conditions for amplification: initial 2 min denaturation at $98^{\circ} \mathrm{C} ; 35$ cycles $-10 \mathrm{~s}$ denaturation at $98^{\circ} \mathrm{C}, 10 \mathrm{~s}$ annealing at $54^{\circ} \mathrm{C}$, and $1.5 \mathrm{~min}$ extension at $72^{\circ} \mathrm{C}$; final 3 min extension at $72^{\circ} \mathrm{C}$.

rDNA clone library was constructed the following procedure, as described previously (Kakikawa et al. 2002); Amplified 16S and 18S rDNA (1.5 and $1.7 \mathrm{~kb}$, respectively) were cloned by ligation to the Hinc II site of plasmid pUC119 and introduced into Escherichia coli JM109 by electropolation (BIO-RAD Lab.). Inserted rDNA 
clones were screened by colony PCR. Then, a total of 685 clones with rDNA insert were divided into 29 representative variants by restriction fragment length polymorphism (RFLP) analysis using restriction enzymes Rs $a$ I and Alu I (TAKARA BIO INC.).

The DNA sequences of cloned rDNA were determined by genetic analyzer (Applied Biosystems), and the related species of dustborne microorganisms were searched by BLAST analysis (http://www.ncbi.nlm.nih.gov/BLAST/) to DNA databases (GenBank/EMBL/DDBJ).

These sequence data of dustborne microorganisms have been submitted to the GenBank database under accession numbers $\mathrm{AB} 451535$ to $\mathrm{AB} 451542$ for the bacteria and $\mathrm{AB} 451531$ to $\mathrm{AB} 451533$ for the fungi.

\section{Results and discussion}

Dusts sampling

Airborne dusts were collected on 0.45 - $\mu \mathrm{m}$ pore-size filter using a balloon with filtration system at 800 and $10 \mathrm{~m}$ above the ground in Dunghuang (40¹0'00" N, 9440'60" E), Aug. 2007. The dusts above Dunhuang City have been known as one of large source areas of Asian dust particles, since Dunhuang City is located at east open area of the Taklimakan Desert surrounded by high mountains (average elevation $>5,000 \mathrm{~m}$ ).

During dusts sampling at $800 \mathrm{~m}$ above the ground, mean temperature and mean relative humidity were $13.6^{\circ} \mathrm{C}$ and $94.1 \%$, respectively. At the same time, mean temperature
Fig. 1 Particle concentrations in the atmosphere of the heights of $800 \mathrm{~m}$ (line) and $10 \mathrm{~m}$ (triangle) at Dunhuang, China (on 17 August 2007)

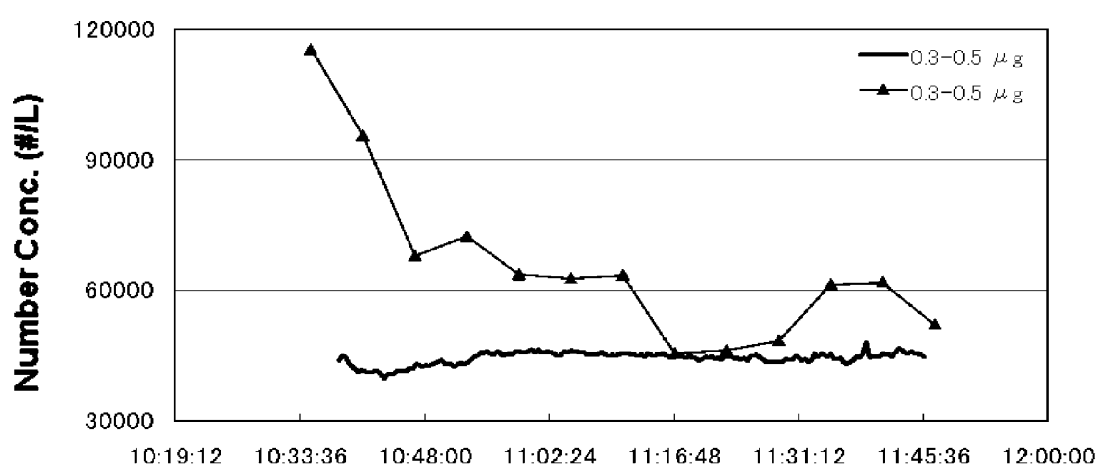

Beijin Time
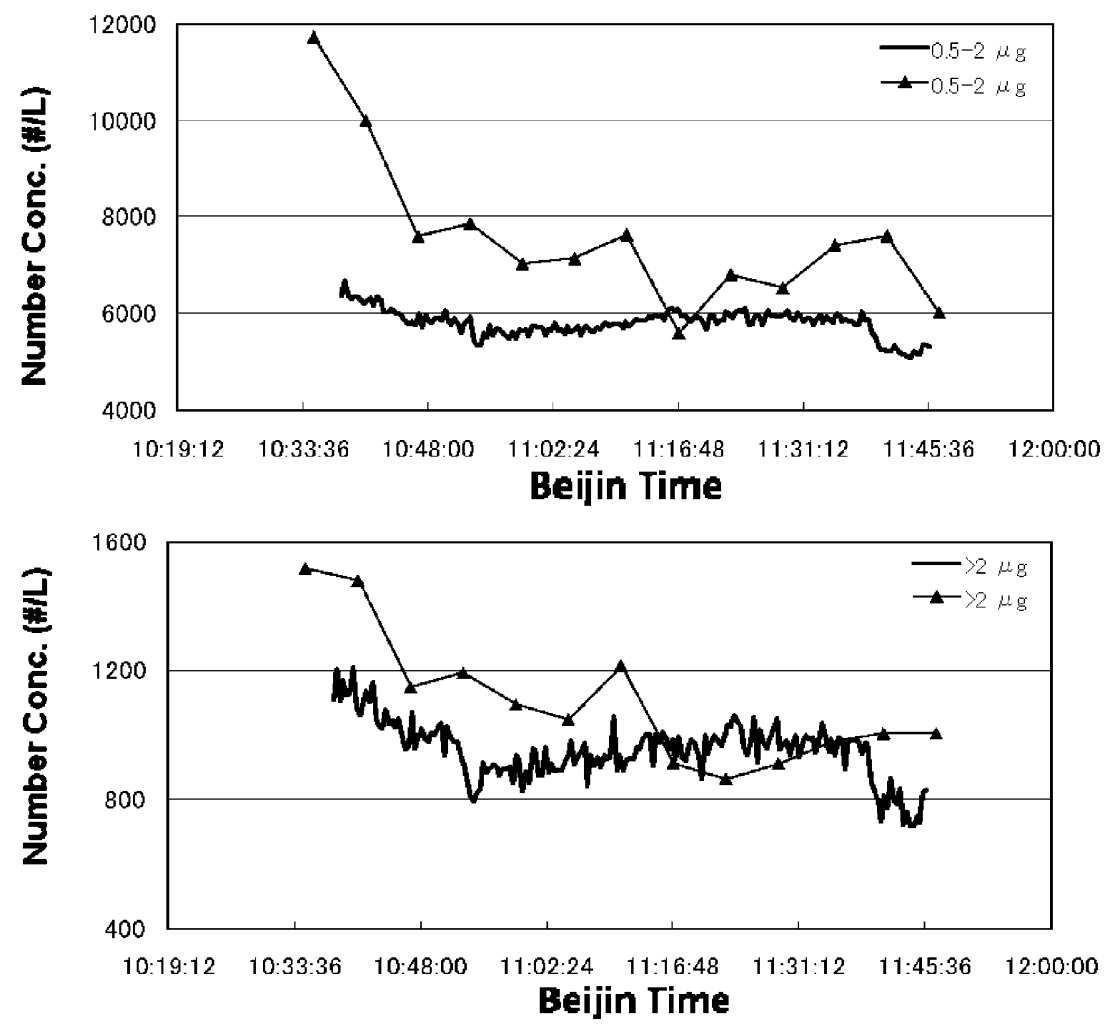
and mean relative humidity on the ground were $23.0^{\circ} \mathrm{C}$ and $63.4 \%$, respectively.

At $800 \mathrm{~m}$ above the ground, the particles with diameter $0.3 \mu \mathrm{m}$ showed number concentration of $50,000 / \mathrm{L}$ and formed about $75.5 \%$ of the total particles on the sampling site (Fig. 1). The particles with diameters $0.5-2.0 \mu \mathrm{m}$ and larger than $2.0 \mu \mathrm{m}$ showed number concentration of $15,000 / \mathrm{L}(23 \%)$ and 1,000/L (1.5\%), respectively. At $10 \mathrm{~m}$ above ground, the particle concentration with size of a diameter $0.3 \mu \mathrm{m}$ was higher than that of $800 \mathrm{~m}$ above the ground, and changes in the number concentration were seen during sampling (Fig. 1). Number concentration of particles with size ranges of $0.5-2.0$ and $>2.0 \mu \mathrm{m}$ at $10 \mathrm{~m}$ above the ground show 15,000/L (17.3\%) and 1,100/L (1.3\%), respectively. These results indicate that the number concentration of particles at $10 \mathrm{~m}$ above the ground was about the same as that of $800 \mathrm{~m}$ above the ground. However, particle concentration at $10 \mathrm{~m}$ height had much variation during sampling time and that at $800 \mathrm{~m}$ height was relatively stable for a long time. It is considered that the change of particle concentration at $10 \mathrm{~m}$ height was large compared with that of $800 \mathrm{~m}$ height in order to disturb the air near the ground by the thermal and frictional effect of earth surface.

By vacuum performance, it was estimated that the dusts particles $(>0.5 \mu \mathrm{m})$ in about $0.7 \mathrm{~m}^{3}$ atmosphere air $800 \mathrm{~m}$ above ground were collected on $0.45 \mu \mathrm{m}$ pore-size filter. Thus, it can be estimated that the $1.12 \times 10^{7}$ dust particles $\left(1.05 \times 10^{7}\right.$ particles with diameter $0.5-2.0 \mu \mathrm{m}$ and $0.07 \times$ $10^{7}$ particles with diameter larger than $2.0 \mu \mathrm{m}$ ) were collected on the filter in this sampling.

\section{DNA contained in Asian dusts}

DNA was extracted from dust particles on the filters with cell wall lytic enzyme, lysozyme, and proteinase $\mathrm{K}$. The amount of DNA was about $0.1 \mu \mathrm{g}$ from the filter of $800 \mathrm{~m}$ above the ground and about $0.2 \mu \mathrm{g}$ from the filter of $10 \mathrm{~m}$ height above the ground.

It was estimated that the number of microorganisms at $800 \mathrm{~m}$ above the ground was $\sim 2 \times 10^{6}$ in the $0.7-\mathrm{m}^{3}$ atmosphere air because $1 \mu \mathrm{g}$ of DNA contains $2 \times 10^{7}$ molecules of bacterial or fungi genome. In $10 \mathrm{~m}$ above the ground, it was estimated $\sim 4 \times 10^{6}$ microorganisms in the $0.7 \mathrm{~m}^{3}$ atmosphere air. It remains to be seen whether these microorganisms were suspended freely or attached to dust particles.

$16 \mathrm{~S}$ rDNA for bacteria $(1.5 \mathrm{kbp})$ and $18 \mathrm{~S}$ rDNA for fungi $(1.6 \mathrm{kbp})$ were amplified by PCR with using universal primers as shown in Fig. 2. The data indicate that the dust particles from heights of 800 and $10 \mathrm{~m}$ include both bacteria and fungi. Since the detected DNA band was rDNA mixture from various bacteria and fungi, rDNA clone library was constructed by using plasmid vector pUC119. Then, clones of 16S rDNA and 18S rDNA were

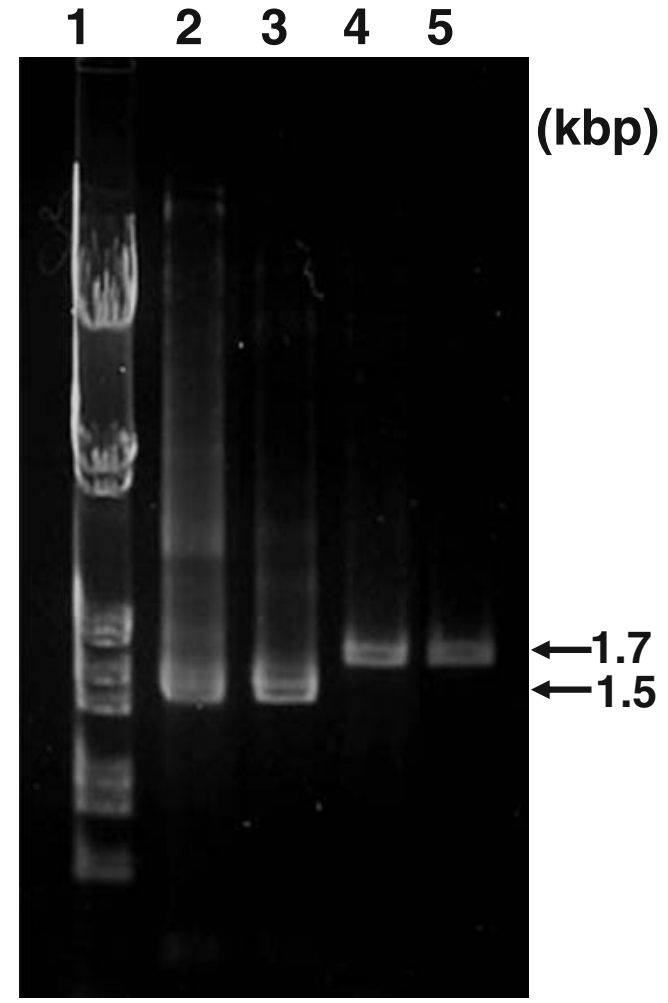

Fig. 2 Amplification of rDNA of microorganisms from dusts sampled in Dunhuang, Gansu Province,China. 16S rDNA (lane 2 from $10 \mathrm{~m}$ height dusts and lane 3 from $800 \mathrm{~m}$ dusts) and 18S rDNA (lane 4 from $10 \mathrm{~m}$ dusts and lane 5 from $800 \mathrm{~m}$ dusts) were run together with size marker (lane 1 ) in $1 \%$ agarose gel

selected by RFLP analysis and sequenced. The related species of dustborne microorganisms were identified by BLAST search to DNA database.

Dustborne microorganisms of $800 \mathrm{~m}$ above the ground in Dunhuang

By nearly complete $18 \mathrm{~S}$ rDNA sequence analysis, it was indicated that closest species to Rickenella fibula (AY771599) and Ceriporiopsis gilvescens (AY219403) were included in the atmosphere $800 \mathrm{~m}$ above the ground in Dunhuang (Table 1). These species are known as sporeforming fungi. The clone DHUP10 fungus shows a high DNA homology of $99.6 \%$ to an uncultured fungus in soil (Moon-van der Staay 2006, AM114819). In DNA database, however, there was no sequence similar to two $18 \mathrm{~S}$ rDNA species derived from the dust particles in atmosphere air of $800-\mathrm{m}$ height. This result suggests the existence of undiscovered eukaryotic species. Recent studies of aquatic environments show unexpected eukaryotic diversity by similar molecular approach (Moon-van der Staay et al. 2001; Lopez-Garcia et al. 2001). It is possible that many novel microorganisms markedly resistant to ultraviolet light or desiccation exist in atmosphere. 
Table 1 Microorganisms in dusts of $800 \mathrm{~m}$ above the ground, Dunhuang, Gansu Province, China

\begin{tabular}{|c|c|c|c|}
\hline $\begin{array}{l}\text { Isotates clones } \\
\text { (Accession no.) }\end{array}$ & $\begin{array}{l}\text { Closest microorganism } \\
\text { in GenBank }\end{array}$ & $\begin{array}{l}\text { \% DNA identity } \\
\text { (matched bases) }\end{array}$ & Comments \\
\hline $\begin{array}{l}\text { DHUP10 Uncultured fungus } \\
\text { (AB451531) }\end{array}$ & $\begin{array}{l}\text { Uncultured fungus } \\
\text { (AM114819) }\end{array}$ & $99.6 \%(1708 / 1714)$ & $\begin{array}{l}\text { Uncultured fungus in historical soil sample. } \\
\text { Isolation_source="soil sample from top 0- } \\
25 \mathrm{~cm} \text { layer of non-fertilized agricultural } \\
\text { field, collected in 1975" (Information from } \\
\text { GenBank submission data) }\end{array}$ \\
\hline $\begin{array}{l}\text { DHUP31 Uncultured fungus } \\
\text { (AB451532) }\end{array}$ & $\begin{array}{l}\text { Rickenella fibula } \\
\text { (AY771599) }\end{array}$ & $97.0 \%(1691 / 1743)$ & Spore-forming fungus. \\
\hline $\begin{array}{l}\text { DHUP42 Uncultured fungus } \\
\text { (AB451533) }\end{array}$ & $\begin{array}{l}\text { Ceriporiopsis gilvescens } \\
\text { (AY219403) }\end{array}$ & $99.5 \%(1670 / 1679)$ & Spore-forming fungus. \\
\hline $\begin{array}{l}\text { DHUP4 Uncultured Brevibacillus } \\
\text { sp. (AB451535) }\end{array}$ & Brevibacillus sp. (AJ313027) & $99.8 \%(1457 / 1460)$ & Spore- forming Gram-positive bacterium. \\
\hline $\begin{array}{l}\text { DHUP7 Uncultured Staphylococcus } \\
\text { sp. (AB451536) }\end{array}$ & $\begin{array}{l}\text { Uncultured Staphylococcus } \\
\text { sp. (EU660426) }\end{array}$ & $99.4 \%(1469 / 1478)$ & $\begin{array}{l}\text { Gram-positive bacterium (Information from } \\
\text { GenBank submission data) }\end{array}$ \\
\hline $\begin{array}{l}\text { DHUP19 Uncultured Rhodococcus } \\
\text { sp. (AB451537) }\end{array}$ & $\begin{array}{l}\text { Rhodococcus sp. } \\
\text { (DQ285075) }\end{array}$ & $99.8 \%(1438 / 1441)$ & $\begin{array}{l}\text { Gram-positive bacterium, photosynthetic } \\
\text { (Information from GenBank submission data) }\end{array}$ \\
\hline $\begin{array}{l}\text { DHUP23 Uncultured Delftia sp. } \\
\text { (AB451538) }\end{array}$ & Delftia sp. (EU880508) & $100 \%(1455 / 1455)$ & $\begin{array}{l}\text { Gram-negative bacterium. } \\
\text { Isolation_source="Pearl River } \\
\text { Estuary sediment, southern China; water } \\
\text { depth: } 50 \mathrm{~cm} \text { " (Information from GenBank } \\
\text { submission data) }\end{array}$ \\
\hline $\begin{array}{l}\text { DHUP34 Uncultured Pseudomonas } \\
\text { sp. (AB451539) }\end{array}$ & $\begin{array}{l}\text { Uncultured Pseudomonas sp. } \\
\text { (DQ088809) }\end{array}$ & $99.7 \%(1459 / 1463)$ & $\begin{array}{l}\text { Gram-negative bacterium. (Information from } \\
\text { GenBank submission data) }\end{array}$ \\
\hline $\begin{array}{l}\text { DHUP36 Uncultured } \\
\text { Agrobacterium sp. (AB451540) }\end{array}$ & $\begin{array}{l}\text { Agrobacterium tumefaciens } \\
\text { (EU592041) }\end{array}$ & $99.9 \%(1407 / 1408)$ & $\begin{array}{l}\text { Gram-negative soil bacterium. Plant pathogen } \\
\text { (grape vines, stone fruits, nut trees, sugar } \\
\text { beets, horse radish, rhubarb etc.). }\end{array}$ \\
\hline $\begin{array}{l}\text { DHUP49 Uncultured Pseudomonas } \\
\text { sp. (AB451541) }\end{array}$ & $\begin{array}{l}\text { Pseudomonas sp. } \\
\text { (AM411620) }\end{array}$ & $99.8 \%(1458 / 1461)$ & $\begin{array}{l}\text { Gram-negative bacterium isolated from deep } \\
\text { sea. (Information from GenBank } \\
\text { submission data) }\end{array}$ \\
\hline $\begin{array}{l}\text { DHUP66 Uncultured bacterium } \\
\text { (AB451542) }\end{array}$ & $\begin{array}{l}\text { Uncultured bacterium } \\
\text { (AY958912) }\end{array}$ & $99.7 \%(1459 / 1462)$ & $\begin{array}{l}\text { Uncultured bacterium. (Information from } \\
\text { GenBank submission data) }\end{array}$ \\
\hline
\end{tabular}

16S rDNA data indicated that dust particles from 800-m height in Dunhuang included bacteria closely related to Brevibacillus sp. (AJ313027, 99.8\%), Rhodococcus sp. (DQ285075, 99.8\%), Delftia sp. (EU880508, 100\%), Pseudomonas sp. (AM411620, 99.8\%), and Agrobacterium tumefaciens (EU592041, 99.9\%). The clone DHUP7, DHUP34, and DHUP66 bacteria show a high DNA homology to uncultured Staphylococcus sp. (EU660426, 99.4\%), uncultured Pseudomonas sp. (DQ088809, 99.7\%), and uncultured bacterium (AY958912, 99.7\%) isolated by culture-independent method.

Three bacterial species of Brevibacillus, Staphylococcus, and Rhodococcus belong to Gram-positive bacteria. Brevibacillus sp. is a spore-former, whereas Rhodococcus sp. has a feature of photosynthetic bacteria. Three species of Delftia, Pseudomonas, and Agrobacterium tumefaciens belong to Gram-negative bacteria, which have lipopolysaccharide and can cause and aggravate respiratory diseases. Agrobacterium tumefaciens was typically found in soil and has been known as a plant pathogen.
It should be noted that clone DHUP23 is closely related to Delftia sp. (EU880508) isolated from river estuary sediment in southern China. Clone DHUP49 is also closely related to Pseudomonas sp. (AM411620) isolated from deep sea. These ocean bacteria, Delftia sp. (EU880508) and Pseudomonas sp. (AM411620) might be of Asian desert origin and have been transported to the sea by desert wind.

These results on dustborne microorganisms of $800 \mathrm{~m}$ above the ground indicate that dusts contain at least eight bacterial and three fungal species including soil bacterium, spore-forming bacterium and plant pathogenic fungi. Thus, these dustborne bacteria and fungi have possibilities of affecting downwind ecosystem.

On the other hand, Maki et al. (2008) detected the dust particles with attached bacteria in the atmosphere in summer over same location, Dunhuang using an epifluorescence microscope. Maki et al. analyzed the bacterial community in the dusts by using the culture-based and denaturing gradient gel electrophoresis methods, and detected a halobacterial community composed of members 
of the genus Bacillus and staphylococcus. Yeo and Kim (2002) reported that four fungi of Aspergillus, Basipetospora, Fusarium, and Penicillium were detected from suspended particulate matter samples taken at Seosan, Korea. According to Wu et al. (2004) and Ho et al. (2005), fungal spores such as Cladsporium, Ganderma, Arthrium, Cercospora, Stemphylium, Pithomyces, Periconia, Alternaria, Botrytis, and Nigrospora had significantly higher number concentrations in Taiwan, during Asian dust event.

From the results of our and other research group, it has been revealed that microorganisms could be transported by airborne dust, although these have differences in the genera of bacteria or fungi. The differences might have been caused by methods or dust sampling points.

Further studies should examine the seasonal variation, transportation change of dustborne microorganisms from dust source region to downwind area and the effects on ecosystem as air quality.

Dustborne microorganisms of the ground in Dunhuang

18S rDNA data show that dust particles of $10 \mathrm{~m}$ above the ground in Dunhuang contain fungi closely related to Henningsomyces sp., Athelia bombacina, Tulasnella sp., Nyssopsora echinata, Wallemia sp. and seem to contain plant pollen of Beta vulgaris, Caprifoliaceae, and Panax notoginseng (data not shown). Nyssopsora echinata is known as a plant pathogen.

Dustborne bacteria on the ground in Dunhung were related to Arthrobacter sp. Ornithinimicrobium sp., Rubellimicrobium thermophilum, Friedmanniella capsulala, Geodermatophilus sp., Cellulomonas sp., Promicromonospora sp., and Cryocola antiquus.

In spite of having collected at the same location, dustborne microorganism species of $800-\mathrm{m}$ height did not consist with that of $10-\mathrm{m}$ height. Dust particles of $800 \mathrm{~m}$ above the ground might have been transported from central and west Taklimakan Desert by west wind. There might be microorganisms which can soar up in the air with dust and, needless to say, microorganisms which cannot soar.

\section{Conclusions}

Dust particles in the atmosphere over Dunhuang City, China, were collected on Aug. 2007. Dustborne microorganisms in the atmosphere over the Dunhuang City were investigated by culture-independent rDNA Analysis. Three fungal species closely related with Rickenella fibula (AY771599), Ceriporiopsis gilvescens (AY219403), uncultured fungus (AM114819), and previously unknown two eukaryotic species were detected in dusts from $800 \mathrm{~m}$ above the ground. Eight bacterial species belonging to the genus
Brevibacillus (AJ313027), Staphylococcus (EU660426), Rhodococcus (DQ285075), Delftia (EU880508), Pseudomonas (DQ088809, AM411620), Agrobacterium (EU592042), and uncultured bacteria (AY958912) were found in dusts from $800 \mathrm{~m}$ above the ground. This bacterial community contains plant pathogen, soil bacteria, and spore-forming bacteria.

These results suggest that the dust carry microorganisms into the atmosphere, facilitate the dispersal of biological particles, and might play a significant role in downwind ecosystem and human health.

The studies on transportation change of dustborne microorganisms from dust source region of China to Korea and Japan, and the seasonal variation of the microorganisms are now in progress.

Acknowledgements This research was supported by the Global Environment Research Fund (RF-072) provided by the Ministry of the Environment, Japan. We thank Dr. Akira Taketo for his suggestion on this study.

Staff members of Meteorological Bureau of Dunghuang City gave us kind technical supports during the balloon-borne observation.

Open Access This article is distributed under the terms of the Creative Commons Attribution Noncommercial License which permits any noncommercial use, distribution, and reproduction in any medium, provided the original author(s) and source are credited.

\section{References}

Biscaue PE, Grousset FE, Revel M, Van der Gaast S, Zielinski GA, Vaars A, Kukla G (1997) Asian provenance of glacial dust (stage 2) in the Greenland Ice Core Summit, Greenland. J Geophys Res 102:26765-26781. doi:10.1029/97JC01249

Chadwick OA, Derry A, Vitousek PM, Huebert BJ, Hedin LO (1999) Changing sources of nutrients during four million years of ecosystem development. Nature 397:491-497. doi:10.1038/17276

Chan C-C, Chuang K-J, Chen W-J, Chamg W-T, Lee C-T, Peng C-M (2008) Increasing cardiopulmonary emergency visits by longrange transported Asian dust storms in Taiwan. Environ Res 106:393-400. doi:10.1016/j.envres.2007.09.006

Chen Y-S, Yang C-Y (2005) Effects of Asian dust storm events on daily hospital admissions for cardiovascular disease in Taipei, Taiwan. J Toxicol Environ Health Part A 68:1457-1464. doi:10.1080/15287390590967388

Chen Y-S, Sheen P-C, Chen E-R, Liu Y-K, Wu T-N, Yang C-Y (2004) Effects of Asian dust storm events on daily mortality in Taipei, Taiwan. Environ Res 95:151-155. doi:10.1016/j.envres.2003.08.008

Choi D-S, Park Y-K, Oh S-K, Yoon H-J, Kim JC, Seo W-J, Cha S-H (1997) Distribution of airborne microorganisms in yellow sands of Korea. J Microbiol 35:1-9

Dawson S, Pace NR (2002) Novel kingdom-level eukaryotic diversity in anoxic environments. Proc Natl Acad Sci USA 99:8324-8329. doi:10.1073/pnas.062169599

Duce RA, Unni CK, Ray BJ, Prospero JM, Merrill JT (1980) Longrange atmospheric transport of soil dust from Asia to the tropical north Pacific: temporal variavility. Science 209:1522-1524. doi:10.1126/science.209.4464.1522

Griffin DW, Garrison VH, Herman JR, Shinn EA (2001) African desert dust in the Caribbean atmosphere: microbiology and public helth. Aerobiologia 17:203-213. doi:10.1023/A:1011868218901 
Griffin DW, Kellogg CA, Garrison VH, Lisle JT, Borden TC, Shinn EA (2003) Atmospheric microbiology in the northern Caribbean during African dust events. Aerobiologia 19:143-157. doi:10.1023/B:AERO.0000006530.32845.8d

Griffin DW, Westphal DL, Gray MA (2006) Airborne microorganisms in the African desert dust corridor over the mid-Atrantic ridge, Ocean Drilling Program, Leg209. Aerobiologia 22:211-226. doi:10.1007/s10453-006-9033-z

Griffin DW, Kubilay N, Kocak M, Gray MA, Borden TC, Shinn AS (2007) Airborne desert dust and aeromicrobiology over the Turkish Mediterranean coastline. Atmos Environ 41:4050-4062. doi:10.1016/j.atmosenv.2007.01.023

Hahn PY, Evans SE, Kottom TJ, Standing JE, Pagano RE, Limper AH (2003) Pneumocystis carinii cell wall beta-glucan induces release of macrophage inflammatory protein-2 from alveolar epithelial cells via a lactosylceramide-mediated mechanism. J Biol Chem 278:2043-2050. doi:10.1074/jbc.M209715200

Ho H-M, Rao CY, Hsu HH, Chiu Y-H, Liu C-M, Chao HJ (2005) Characteristics and determinants of ambient fungal spores in Hualien, Taiwan. Atmos Environ 39:5839-5850. doi:10.1016/j. atmosenv.2005.06.034

Ichinose T, Nishikawa M, Takano H, Sera N, Sadakane K, Mori I, Yanagisawa R, Oda T, Tamura H, Hiyoshi K, Quan H, Tomura S, Sakamoto T (2005) Pulmonary toxicity induced by intratracheal instillation of Asian yellow dust (Kosa) in mice. Environ Toxicol Pharmacol 20:48-56. doi:10.1016/j.etap.2004.10.009

Iwasaka Y, Yamato M, Imasu R, Ono A (1988) Transport of Asian dust (KOSA) particles; importance of weak KOSA events on the geochemical cycle of soil particles. Tellus, ser. B 40:494-503

Iwasaka Y, Shi GY, Yamada M, Matsuki A, Trochkine D, Kim YS, Zhang D, Nagatani T, Shibata T, Nagatani M, Nakata H, Shen Z, Chen B (2003) Importance of dust particles in the free troposphere over the Taklamakan Desert: Electron microscopic experiments of particles collected with a balloonborne particle impactor at Dunhuang, China. J Geophys Res 108:ACE12-1ACE12-10

Kakikawa M, Yokoi K-J, Kimoto H, Nakano M, Kawasaki K-I, Taketo A, Kodaira K-I (2002) Molecular analysis of the lysis protein Lys encoded by Lactococcus plantarum phage $\varphi \mathrm{g} 1 \mathrm{e}$. Gene 299:227-234. doi:10.1016/S0378-1119(02)01076-4

Kellogg CA, Griffin DW, Garrison VH, Peak KK, Royall N, Smith RR, Shinn EA (2004) Characterization of aerosolized bacteria and fungi from desert dust events in Mali, West Africa. Aerobiologia 20:99 110. doi:10.1023/B:AERO.0000032947.88335.bb

Kennedy MJ, Chadwick OA, Vitousek PM, Derry LA, Hendricks DM (1998) Changing sources of base cations during ecosystem development, Hawaiian Islands. Geology 26:1015-1018. doi:10.1130/0091-7613(1998)026<1015:CSOBCD>2.3.CO;2

Kurosaki Y, Mikami M (2005) Regional differences in the characteristics of dust event in east Asia: relationship among dust outbreak, surface wind, and land surface condition. J Meteorol Soc Jpn 83:1-18. doi:10.2151/jmsj.83A.1

Kwon HJ, Cho SH, Chun Y, Lagarde F, Pershagen G (2002) Effects of Asian dust events on daily mortality in Seoul, Korea. Environ Res 90:1-5. doi:10.1006/enrs.2002.4377

Lee JT, Son JY, Cho YS (2007) A comparison of mortality related to urban air particles between periods with Asian dust days and without Asian dust days in Seoul, Korea, 2000-2004. Environ Res 105:409-413. doi:10.1016/j.envres.2007.06.004

Lopez-Garcia P, Rodriguez-Valera F, Pedros-Alio C, Moreira D (2001) Unexpected diversity of small eukaryotes in deep-sea Antarctic plankton. Nature 409:603-607. doi:10.1038/35054537

Maki T, Susuki S, Kobayashi F, Kakikawa M, Yamada M, Higashi T, Chen B, Shi G, Hong C, Tobo Y, Hasegawa H, Ueda K, Iwasaka Y (2008) Phylogenetic diversity and vertical distribution of a halobacterial community in the atmosphere of an Asian dust
(KOSA) source region, Dunhuang City. Air Qual Atmos Health 1:81-89. doi:10.1007/s11869-008-0016-9

Matsuki A, Iwasaka Y, Osada K, Matsunaga K, Kido M, Inomata Y, Trochkine D, Nishita C, Nezuka T, Sakai T, Zhang D, Kwon SA (2003) Seasonal dependence of the longrange transport and vertical distribution of the free tropospheric aerosols over East Asia: on the basis of aircraft and lidar measurements, and isentropic trajectory analysis. J Geophys Res 108:ACE31-1ACE31-10

Moon-van der Staay SY, Tzeneva V, van der Staay GWM, de Vos WM, Smidt H, Hackstein JHP (2006) Eukaryotic diversity in historical soil samples. FEMS Microbiol Ecol 57:420-428. doi:10.1111/j.1574-6941.2006.00130.x

Moon-van der Staay SY, De Wachter R, Vaulot D (2001) Oceanic 18S rDNA sequences from picoplankton reveal unsuspected eukaryotic diversity. Nature 409:607-610. doi:10.1038/35054541

Nikaido H, Vaara M (1985) Molecular basis of bacterial outer membrane permeability. Microbiol Rev 49:1-32

Park JW, Lim YH, Kyung SY, An CH, Lee SP, Jeong SH, Ju Y-S (2005) Effects of ambient particulate matter on peak expiatory flow rates and respiratory symptoms of asthmatics during Asian dust periods in Korea. Respirology 10:470-476. doi:10.1111/ j.1440-1843.2005.00728.x

Prospero JM, Blades E, Mathison G, Naidu R (2005) Interhemispheric transport of viable fungi and bacteria from Africa to Caribbean with soil dust. Aerobiologia 21:1-19. doi:10.1007/s10453-004-5872-7

Rondon MR, August PR, Bettermann AD, Brady SF, Grossman TH, Liles MR, Loiacono KA, Lynch BA, MacNeil IA, Minor C, Tiong CL, Gilman M, Osburne MS, Clardy J, Handelsman J, Goodman RM (2000) Cloning the soil metagenome: a strategy for accessing the genetic and functional diversity of uncultured microorganisms. Appl Environ Microbiol 66:2541-2547

Sakai T, Shibata T, Kwon SA, Kim YS, Tamura K, Iwasaka Y (2000) Free tropospheric backscatter, depolarization ratio, and relative humidity measured with the Raman lidar at Nagoya in 19940997: contributions of aerosols from the Asian continent and the Pacific Ocean. Atmos Environ 34:431-442. doi:10.1016/S13522310(99)00328-3

Shaun MB, Stephen JF (2006) The structure and synthesis of the fungal cell wall. BioEsseys 28:799-808. doi:10.1002/bies.20441

Sun J, Zhang M, Liu T (2001) Spatial and temporal characteristics of dust storms in China and its surrounding regions, 1960-1999: relations to source area and climate. J Geophys Res 106:1032510333. doi:10.1029/2000JD900665

Torsvik V, Goksoyr J, Daae FL (1990) High diversity in DNA of soil bacteria. Appl Environ Microbiol 56:782-787

Tsunogai S, Kondo T (1982) Sporadic transport and deposition of continental aerosols to the Pacific Ocean. J Geophys Res 87:8870-8874. doi:10.1029/JC087iC11p08870

Tulic MK, Wale JL, Holt PG, Sly PD (2000) Modification of the inflammatory response to allergen challenge after exposure to bacterial lipopolysaccharide. Am J Respir Cell Mol Biol 22:604 612

Vassallo R, Standing JE, Limper AH (2000) Isolated Pneumocystis carinii cell wall glucan provokes lower respiratory tract inflammatory responses. J Immunol 164:3755-3763

Venter JC, Remington K, Heidelberg JF, Halpern AL, Rusch D, Eisen JA, Wu D, Paulsen L, Nelson KE, Nelson W, Fouta DE, Levy S, Knap AH, Lomas MW, Nealson K, White O, Peterson J, Hoffman J, Parsons R, Baden-Tillson H, Pfannkoch C, Rogers Y-H, Smith HO (2003) Environmental genome shotgun sequencing of the Sargasso sea. Science 304:66-74. doi:10.1126/ science. 1093857

Weisburg WG, Barns SM, Pelletier DA, Lane DJ (1991) 16S ribosomal DNA amplification for phylogenetic study. J Bacteriol 173:697-703 
Wu Y, Singer M, Thouron F, Alaoui-EI-Azher M, Touqui L (2002) Effect of surfactant on pulmonary expression of type IIA PLA(2) in an animal model of acute lung injury. Am J Physiol Lung Cell Mol Physiol 282:L743-L750

Wu P-C, Tsai JC, Li F-C, Lung S-C, Su H-J (2004) Increased levels of ambient fungal spores in Taiwan are associated with dust events from China. Atmos Environ 38:4879-4886. doi:10.1016/j.atmosenv.2004.05.039

Yamada M, Iwasaka Y, Matsuki A, Trochkine D, Kim YS, Zhang D, Nagatani T, Shi GY, Nagatani M, Nakata H, Shen Z, Chen B, Li $\mathrm{G}$ (2005) Feature of dust particles in the spring free troposphere over Dunhung in Northwestern China: electron microscopic experiments on individual particles collected with ballon-borne impacter. Water Air Soil Pollut 5:231-250. doi:10.1007/s11267005-0741-0

Yeo H-G, Kim J-H (2002) SPM and fungal spores in ambient air of west Korea during the Asian dust (Yellow sand) period. Atmos Environ 36:5437-5442. doi:10.1016/S1352-2310(02)00672-6

Zdanowicz C, Hall G, Vaive J, Amelin Y, Percival J, Girard I, Biscaye P, Bory A (2006) Asian dustfall in the St. Elias Mountains, Yukon, Canada. Geochimica 70:3493-3507. doi:10.1016/j. gca.2006.05.005 